\title{
Migraine progression in subgroups of migraine based on comorbidities
}

Results of the CaMEO Study

Richard B. Lipton, MD, Kristina M. Fanning, PhD, Dawn C. Buse, PhD, Vincent T. Martin, MD,

Lee B. Hohaia, PharmD, Aubrey Manack Adams, PhD, Michael L. Reed, PhD, and Peter J. Goadsby, MD

Neurology ${ }^{\circledR}$ 2019;93:e2224-e2236. doi:10.1212/WNL.0000000000008589

\author{
Correspondence \\ Dr. Lipton \\ Richard.Lipton@ \\ einstein.yu.edu
}

\begin{abstract}
Objective

To test the hypothesis that statistically defined subgroups of migraine (based on constellations of comorbidities and concomitant conditions; henceforth comorbidities), previously identified using Chronic Migraine Epidemiology and Outcomes (CaMEO) Study data, differ in prognosis, as measured by rates of progression from episodic migraine (EM) to chronic migraine (CM).
\end{abstract}

\section{Methods}

The onset of $\mathrm{CM}$ was assessed up to 4 times over 12 months in individuals with $\mathrm{EM}$ and $\geq 1$ comorbidity at baseline, based on constellations of comorbidities (comorbidity classes). The "fewest comorbidities" class served as reference. Individuals completing $\geq 1$ follow-up survey from the web-based CaMEO Study were included. Covariates included sociodemographic variables and headache characteristics. Sex, income, cutaneous allodynia, and medication overuse were modeled as binary variables; age, body mass index, headache-related disability (Migraine Disability Assessment [MIDAS]), and Migraine Symptom Severity Scale as continuous variables. CM onset was assessed using discrete time analysis.

\section{Results}

In the final sociodemographic model, all comorbidity classes had significantly elevated hazard ratios (HRs) for risk of progression to CM from EM, relative to fewest comorbidities. HRs for $\mathrm{CM}$ onset ranged from 5.34 (95\% confidence interval $[\mathrm{CI}] 3.89-7.33 ; p \leq 0.001$ ) for most comorbidities to 1.53 (95\% CI 1.17-2.01; $p<0.05)$ for the respiratory class. After adjusting for headache covariates independently, each comorbidity class significantly predicted CM onset, although HRs were attenuated.

\section{Conclusions}

Subgroups of migraine identified by comorbidity classes at cross-section predicted progression from EM (with $\geq 1$ comorbidity at baseline) to CM. The relationship of comorbidity group to $\mathrm{CM}$ onset remained after adjusting for indicators of migraine severity, such as MIDAS.

\section{Clinicaltrials.gov identifier}

NCT01648530. 


\section{Glossary}

AMPP = American Migraine Prevalence and Prevention; BMI = body mass index; CaMEO = Chronic Migraine Epidemiology and Outcomes; $\mathbf{C I}=$ confidence interval; $\mathbf{C M}=$ chronic migraine; $\mathbf{E M}=$ episodic migraine; $\mathbf{H R}=$ hazard ratio; ICHD-3 = International Classification of Headache Diseases, 3rd Edition; LCA = latent class analysis; MIDAS = Migraine Disability Assessment; MSSS = Migraine Symptom Severity Scale.

Migraine is a complex neurologic disease with multiple environmental and genetic risk factors and substantial phenotypic heterogeneity. ${ }^{1}$ The natural disease course of episodic migraine (EM) can involve the progression to chronic migraine $(\mathrm{CM})$, remission to less frequent or no migraine, or change of headache type. ${ }^{2}$ Increased headache day frequency, medication overuse, depression, and cutaneous allodynia are associated with progression to $\mathrm{CM}^{3,4} \mathrm{MRI}^{5,6}$ and gene association studies ${ }^{1}$ have previously identified subgroups of migraine with features predisposing to progression to $\mathrm{CM}$.

Migraine is also associated with concomitant conditions or comorbidities (conditions occurring with migraine at a rate greater than expected based on chance alone ${ }^{7}$ ) (hereafter comorbidities) such as asthma, ${ }^{8}$ rhinitis, ${ }^{9}$ depression and anxiety, ${ }^{10}$ and chronic pain disorders, ${ }^{11}$ with asthma, ${ }^{12}$ depression, ${ }^{13}$ and noncephalic pain disorders ${ }^{14}$ identified as predictors of progression to CM. Results from previous research using cluster analysis suggest that people from subgroups of migraine defined based on comorbidity profiles may differ in prognosis, response to treatment, and underlying biology. ${ }^{15}$

The Chronic Migraine Epidemiology and Outcomes (CaMEO) Study was a web-based survey study using crosssectional modules with longitudinal follow-up assessments. It was designed to characterize the natural course of migraine and describe related comorbidities and patterns of treatment in a representative US sample of people with migraine. ${ }^{16}$ Previously, data from the CaMEO Study were modeled using latent class analysis (LCA) to identify subgroups of migraine based on comorbidity profiles. ${ }^{7}$ These subgroups differed in demographic profiles, disability, and headache characteristics. The present analysis uses discrete time hazard modeling to estimate comorbid health predictors of progression from EM to CM.

\section{Methods}

\section{Study design}

The CaMEO Study (ClinicalTrials.gov identifier: NCT01648530) was an Internet-based study with crosssectional modules and longitudinal follow-ups designed to assess a range of data including comorbidities and migraine characteristics, including progression of migraine to $\mathrm{CM}$ over 1 year. ${ }^{16}$ Recruiting and screening occurred between September and October 2012. Participants were recruited using quota sampling, to ensure that participants of the invited sample were balanced against key population demographics, from an Internet research panel (Research Now, Plano, TX) that included 2.4 million active US members. A total of 489,537 members of the panel were invited to participate; 80,783 (16.5\%) responded, 58,418 ( $72.3 \%$ of respondents) provided usable surveys for analysis (i.e., $\geq 20 \%$ of the survey was complete and headache status could be determined), and $16,789(28.7 \%$ of those respondents with usable data) met study inclusion criteria, reflecting modified International Classification of Headache Diseases, 3rd Edition (ICHD-3) ${ }^{17}$ criteria for migraine.

\section{Study participants}

Respondents were eligible for inclusion in the study if they met CaMEO Study criteria and volunteered to participate. ${ }^{16}$ Migraine criteria were assessed using the validated American Migraine Study/American Migraine Prevalence and Prevention (AMPP) Study diagnostic screener, ${ }^{18-20}$ which uses a modification of the ICHD-3 migraine criteria, ${ }^{17}$ and has been demonstrated previously to have a sensitivity of 1.00 and a specificity of 0.82 for the diagnosis of migraine when used in self-report populations. ${ }^{18}$ Respondents with migraine were defined as those meeting modified ICHD-3 migraine criteria, and those with CM also had $\geq 15$ headache days per month averaged over the preceding 3 months based on SilbersteinLipton criteria. ${ }^{21}$ This approach, using patient self-report, has been demonstrated to have a sensitivity of 0.90 and a specificity of 0.83 , with a good to excellent intertest reliability $(\kappa=$ 0.76 ) for $\mathrm{CM}^{22}$ Although participation rates in the Internetbased CaMEO Study were modest compared to those of the mail survey-based AMPP Study ( $16.5 \%$ vs $64.9 \%$, respectively), formal comparisons of baseline demographics and headache characteristics of the study populations demonstrated that they were similar, leading to the conclusion that the CaMEO Study respondents were representative of the US population with migraine. ${ }^{23}$

\section{Assessments}

The Screening, Core, and Barriers to Care modules together represent baseline assessments from the CaMEO Study cohort and provided data for respondent demographics and headache characteristics and treatment. Comorbidities were collected at stage 2 of the CaMEO Study via a questionnaire designed using validated instruments where possible and a list of questions on common conditions (Comorbidities/ Endophenotype module). Self-reports of 62 different symptoms and conditions were available for the analysis and those conditions judged by clinical experts to require a medical 
diagnosis for reliable reporting were assessed based on selfreport of a physician diagnosis. Data from Screening, Core, Barriers to Care, and Comorbidities/Endophenotype modules were used to inform the LCA and identify subgroups of people with migraine based on comorbidity profiles, providing the main variable of interest for this current analysis. Cross-sectional data from the Core/Snapshot modules collected every 3 months for 12 months were used in this analysis to inform progression from migraine to $\mathrm{CM}$.

\section{Standard protocol approvals, registrations, and patient consents}

Data included in this analysis were from the CaMEO Study. The CaMEO Study was approved by the institutional review board of the Albert Einstein College of Medicine, which waived written informed consent for study volunteers who had the right to accept or refuse participation in the survey.

\section{Latent class analysis}

Using LCA, we identified 8 subgroups of migraine based on patients reporting $\geq 1$ comorbidities. ${ }^{7}$ Preliminary LCA modeling was undertaken with 62 comorbidity variables and patients reporting $\geq 1$ comorbidity, identifying the 8-class model as the model of best fit. Subsequently, variable reduction was undertaken to help enhance the interpretability of the model, leaving 22 comorbidity variables. LCA modeling in combination with clinical judgment identified the 8-class model as having the best fit to the data and the most distinctive classes. The classes identified by LCA and being further investigated in this report are as follows: class 1, many comorbidities (most comorbidities); class 2, respiratory/ psychiatric (resp/psych); class 3, respiratory/pain (resp/ pain); class 4, respiratory; class 5 , psychiatric; class 6 , cardiovascular; class 7, pain; class 8, few comorbidities (fewest comorbidities) (figure).

\section{Discrete time hazard analysis}

The discrete time hazard model is an extension of the proportional hazard model, incorporating conditional odds of an event occurring in a series of subsequent discrete time periods. This model accommodates censored data (i.e., when information about the event is incomplete because it is missing or occurs outside of the observation period). For this analysis, a Cox model with a discrete time variable was used, as data were collected at 3-month intervals. The main statistic reported is the hazard ratio (HR).

\section{Analysis approach}

The LCA-derived comorbidity classes were used as the basis for discrete time hazard models examining time to CM onset across the 8 comorbidity classes over 4 follow-up periods (i.e., 3, 6, 9, and 12 months after the baseline survey). The analysis sample included those with $\geq 1$ of 62 comorbidities included in the LCA and $\geq 1$ wave of followup data beyond baseline. As the analysis sought to predict $\mathrm{CM}$ onset, those who had $\mathrm{CM}$ at baseline were also excluded.
A range of sociodemographic and headache characteristics were used as covariates, including age, body mass index (BMI), sex, income $(<\$ 50,000[40.9 \%$ of respondents $]$ vs $\geq \$ 50,000$ [59.1\% of respondents]), race, Migraine Disability Assessment (MIDAS), allodynia (Allodynia Symptom Checklist $[<3$ indicates no allodynia vs $\geq 3$ indicates mild or worse allodynia $\left.{ }^{24}\right]$ ), the Migraine Symptom Severity Score (MSSS), and medication overuse at baseline. The MSSS is a composite index that incorporates the frequency of 7 primary migraine features (unilateral pain, pulsatile pain, moderate or severe pain intensity, routine activities worsen pain, nausea, photophobia, and phonophobia). Possible responses were $1=$ never, $2=$ rarely, $3=$ less than half the time, or $4=$ half the time. The overall MSSS score ranges from 7 to 28 and was calculated by summing scores for each of the 7 headache features assessed. Medication overuse was assessed as regular overuse of acute migraine treatment for $>3$ months including acetylsalicylic acid, nonsteroidal antiinflammatory drugs, and acetaminophen [paracetamol] for $\geq 15 \mathrm{~d} /$ mo and ergotamines, triptans, opioids, or combination analgesics on $\geq 10 \mathrm{~d} / \mathrm{mo}^{17} \mathrm{Sex}$, income, allodynia, and medication overuse were modeled as binary variables, while age, BMI, MIDAS, and MSSS were modeled as continuous variables, with age and MIDAS being modeled based on 10year age and 10-point groupings, respectively. The LCAderived comorbidity class was the main predictor variable of interest, with class 8 (fewest comorbidities class) serving as the reference group. The comorbidity classes were included as a single variable.

Three different modeling approaches were undertaken to ensure validity of the results. Discrete time models were run in a nested fashion; sociodemographics were entered first, followed by headache characteristics and treatment variables (headache-related disability [MIDAS], MSSS, allodynia, and medication overuse), which were entered one at a time, then removed before adding the next variable. These models were assessed to determine if headache characteristics accounted for the majority of the variation in progression to $\mathrm{CM}$ observed. Variables that did not significantly contribute (i.e., $p$ values $>0.05$ ) were trimmed from final models. After sociodemographic and headache variable models were completed, all significant variables were entered into a set of forward and backward stepwise models. Forward stepwise regression is an automated process that first enters the variable whose inclusion gives the most statistically significant improvement in model fit and then continues to add variables until there is no further significant improvement in fit. Backwards regression starts with all variables included in the model and takes out the variable whose removal results in least deterioration in model fit, continuing until no additional variable can be removed without significant loss of model fit. $p<0.05$ was considered statistically significant. Missing data were negligible $(<5 \%)$ and no imputation measures were employed. All analyses were performed using IBM SPSS Statistics, version 20.0 (IBM, Armonk, NY; 2011). 
Figure Conditional probability that a member of a comorbidity class would self-report having given comorbidity/concomitant condition

\begin{tabular}{|c|c|c|c|c|c|c|c|c|c|}
\hline & Class 1 & Class 2 & Class 3 & Class 4 & Class 5 & Class 6 & Class 7 & Class 8 & \\
\hline & $\begin{array}{c}\text { Most } \\
\text { comorbidities } \\
(n=676 ; \\
5.7 \%)\end{array}$ & $\begin{array}{c}\text { Resp/psych } \\
\text { (n = 1,332; } \\
\text { 11.3\%) }\end{array}$ & $\begin{array}{c}\text { Resp/pain } \\
\text { (n = 913; } \\
7.7 \%)\end{array}$ & $\begin{array}{c}\text { Respiratory } \\
(\mathrm{n}=2,355 ; \\
19.9 \%)\end{array}$ & $\begin{array}{c}\text { Psychiatric } \\
\text { (n = 898; } \\
7.6 \%)\end{array}$ & $\begin{array}{c}\text { Cardiovascula } \\
\text { (n=917; } \\
7.7 \%)\end{array}$ & $\begin{array}{c}\text { Pain } \\
(n=720 \\
6.1 \%)\end{array}$ & $\begin{array}{c}\text { Fewest } \\
\text { comorbidities } \\
(n=4,026 ; \\
34.0 \%)\end{array}$ & $\begin{array}{c}\text { Average } \\
\text { probability } \\
\text { across } \\
\text { classes }\end{array}$ \\
\hline \multicolumn{10}{|l|}{ Respiratory } \\
\hline Allergies (SR-PD) & $70 \%$ & $69 \%$ & $73 \%$ & $60 \%$ & $23 \%$ & $34 \%$ & $22 \%$ & $21 \%$ & $32 \%$ \\
\hline Bronchitis (SR-PD) & $70 \%$ & $67 \%$ & $75 \%$ & $64 \%$ & $16 \%$ & $36 \%$ & $19 \%$ & $15 \%$ & $30 \%$ \\
\hline Chronic bronchitis (SR-PD) & $27 \%$ & $13 \%$ & $16 \%$ & $7 \%$ & $0 \%$ & $4 \%$ & $4 \%$ & $1 \%$ & $3 \%$ \\
\hline Sinusitis (SR-PD) & $79 \%$ & $89 \%$ & $89 \%$ & $88 \%$ & $24 \%$ & $48 \%$ & $24 \%$ & $20 \%$ & $41 \%$ \\
\hline \multicolumn{10}{|l|}{ Cardiovascular } \\
\hline Hypertension (SR-PD) & $54 \%$ & $22 \%$ & $45 \%$ & $8 \%$ & $8 \%$ & $74 \%$ & $21 \%$ & $7 \%$ & $24 \%$ \\
\hline Diabetes (SR-PD) & $27 \%$ & $7 \%$ & $14 \%$ & $2 \%$ & $3 \%$ & $31 \%$ & $8 \%$ & $2 \%$ & $9 \%$ \\
\hline High cholesterol (SR-PD) & $58 \%$ & $21 \%$ & $46 \%$ & $11 \%$ & $11 \%$ & $75 \%$ & $31 \%$ & $11 \%$ & $28 \%$ \\
\hline \multicolumn{10}{|l|}{\begin{tabular}{|l|} 
Digestive \\
\end{tabular}} \\
\hline Gastrogeophageal reflux (SR-PD) & $55 \%$ & $26 \%$ & $46 \%$ & $11 \%$ & $8 \%$ & $22 \%$ & $14 \%$ & $3 \%$ & $12 \%$ \\
\hline Irritable bowel syndrome (SR-PD) & $36 \%$ & $19 \%$ & $23 \%$ & $9 \%$ & $10 \%$ & $4 \%$ & $8 \%$ & $2 \%$ & $7 \%$ \\
\hline \multicolumn{10}{|l|}{\begin{tabular}{|l|} 
Psychiatric \\
\end{tabular}} \\
\hline Anxiety (SR-PD) & $93 \%$ & $95 \%$ & $14 \%$ & $8 \%$ & $92 \%$ & $15 \%$ & $21 \%$ & $4 \%$ & $28 \%$ \\
\hline Depression (SR-PD) & $88 \%$ & $76 \%$ & $33 \%$ & $17 \%$ & $74 \%$ & $22 \%$ & $33 \%$ & $9 \%$ & $31 \%$ \\
\hline Panic (SR-PD) & $51 \%$ & $42 \%$ & $1 \%$ & $1 \%$ & $31 \%$ & $2 \%$ & $2 \%$ & $0 \%$ & $7 \%$ \\
\hline PTSD (SR-PD) & $30 \%$ & $13 \%$ & $4 \%$ & $2 \%$ & $11 \%$ & $3 \%$ & $5 \%$ & $1 \%$ & $4 \%$ \\
\hline \multicolumn{10}{|l|}{ Joint/pain } \\
\hline Arthritis (SR-PD) & $41 \%$ & $17 \%$ & $33 \%$ & $10 \%$ & $6 \%$ & $25 \%$ & $24 \%$ & $4 \%$ & $14 \%$ \\
\hline Chronic back pain (SR) & $77 \%$ & $28 \%$ & $60 \%$ & $14 \%$ & $14 \%$ & $21 \%$ & $68 \%$ & $9 \%$ & $25 \%$ \\
\hline Chronic pain (SR) & $55 \%$ & $8 \%$ & $25 \%$ & $2 \%$ & $3 \%$ & $4 \%$ & $30 \%$ & $1 \%$ & $8 \%$ \\
\hline Fibromyalgia (SR-PD) & $31 \%$ & $5 \%$ & $14 \%$ & $1 \%$ & $1 \%$ & $4 \%$ & $7 \%$ & $1 \%$ & $3 \%$ \\
\hline Neck pain (SR) & $82 \%$ & $53 \%$ & $79 \%$ & $36 \%$ & $32 \%$ & $33 \%$ & $76 \%$ & $26 \%$ & $40 \%$ \\
\hline Osteoarthritis (SR-PD) & $35 \%$ & $9 \%$ & $33 \%$ & $6 \%$ & $2 \%$ & $19 \%$ & $14 \%$ & $2 \%$ & $8 \%$ \\
\hline \multicolumn{10}{|l|}{ Central nervous system } \\
\hline Insomnia (SR) & $79 \%$ & $63 \%$ & $58 \%$ & $33 \%$ & $44 \%$ & $35 \%$ & $49 \%$ & $23 \%$ & $37 \%$ \\
\hline Restless leg syndrome (SR-PD) & $26 \%$ & $7 \%$ & $11 \%$ & $3 \%$ & $3 \%$ & $5 \%$ & $6 \%$ & $1 \%$ & $4 \%$ \\
\hline Vertigo (SR) & $60 \%$ & $32 \%$ & $38 \%$ & $16 \%$ & $16 \%$ & $18 \%$ & $27 \%$ & $8 \%$ & $17 \%$ \\
\hline
\end{tabular}

The heat map is based on the comorbidity classes of migraine as derived by latent class analysis of Chronic Migraine Epidemiology and Outcomes (CaMEO) comorbidities/endophenotype data. The heat map was created by assigning the color green to the cell that holds the minimum probability value for all comorbidities and classes. The cell that holds the median probability is colored yellow, and the cell that holds the maximum value is colored red. All other cells are colored proportionally. Psych = psychiatric; PTSD = posttraumatic stress disorder; Resp = respiratory; SR = self-reported symptoms; SR-PD = self-reported physician diagnosis of condition. Reproduced with permission from Lipton RB, Fanning KM, Buse DC, et al. Identifying natural subgroups of migraine based on comorbidity and concomitant condition profiles: results of the Chronic Migraine Epidemiology and Outcomes (CaMEO) Study. Headache 2018;58:933-947.7

\section{Data availability}

Data reported in this manuscript are available within the article. Additional data from the CaMEO Study may be requested at allerganclinicaltrials.com/PatientDataRequest.htm.

\section{Results}

\section{Analysis population}

A total of 58,418 individuals provided valid returns to CaMEO baseline surveys; 16,763 individuals met case definition for migraine and were sent the CaMEO Study Comorbidities/Endophenotype module, providing a total of 12,810 valid returns. ${ }^{16}$ We excluded persons with $\mathrm{CM}$ at baseline $(\mathrm{n}=1,111)$, persons who did not complete any follow-up survey $(n=2,296)$, and, per the initial LCA, persons free of comorbidities $(n=745)$, leaving an eligible sample of 8,658 individuals with EM.

\section{Sociodemographics}

The final population for this analysis had a mean (SD) age of 43.2 (14.7) years, a mean (SD) BMI of $28.6(7.6) \mathrm{kg} / \mathrm{m}^{2}$, and $75.0 \%$ were women (table 1). The distribution of individuals across comorbidity classes was variable, from 409 (4.7\%) members of class 1 (most comorbidities) to 3,054 (35.3\%) members of the reference group (class 8 , fewest comorbidities). Demographic and clinical characteristics varied across classes (table 1); class 5 (psychiatric) had the youngest mean (SD) age, 36.3 (12.4) years, and class 6 (cardiovascular) the highest (55.0 [12.2] years). Compared with other classes, members of class 6 (cardiovascular) were more likely to be men (41.4\%) and those of class 2 (respiratory/psychiatric) were most likely to be 
women (85.3\%). Individuals in class 1 (most comorbidities) had the highest mean (SD) BMI $\left(32.4[8.4] \mathrm{kg} / \mathrm{m}^{2}\right)$ and class 8 (fewest comorbidities) the lowest $\left(27.2[7.0] \mathrm{kg} / \mathrm{m}^{2}\right)$.

\section{Headache characteristics}

Similarly, headache characteristics varied across the comorbidity classes (table 1). The median MIDAS score was 6.0; 2,960 respondents (34.2\%) were MIDAS grade III or IV at baseline. The mean (SD) MSSS score was 15.3 (3.2), with mean (SD) monthly headache days of 3.5 (3.2). Allodynia was reported by $3,844(44.4 \%)$ respondents, and 1,028 (11.9\%) met criteria for medication overuse (table 1).

Class 1 (most comorbidities) was most likely to be associated with severe headache-related disability (MIDAS grade IV; $37.0 \%$ ); class 6 (cardiovascular, 10.9\%) and 8 (fewest comorbidities, $12.4 \%$ ) were least likely. Similarly, allodynia was most likely to be observed in members from class 1 (most comorbidities, $60.1 \%$ ), and least likely in members from class 6 (cardiovascular, 36.0\%), and class 8 (fewest comorbidities, $36.6 \%)$. Reported medication overuse was highest in class 1 (most comorbidities, 27.6\%) and lowest for class 8 (fewest comorbidities, $7.6 \%$ ) and class 4 (respiratory, 9.8\%).

\section{Discrete time hazard models}

Initial CM progression hazard models were performed with only the LCA comorbidity classes and sociodemographic variables (i.e., sex, age, race, income, and BMI) included. Race did not significantly contribute (HR [ $95 \%$ confidence interval (CI) 1.05 [0.82-1.35]) so it was trimmed from the model. The HR for sex was also not significant $(1.20$ [95\% CI 0.99-1.45]); however, it was left in the model because sex differences contribute to migraine epidemiology and comorbidity profiles. ${ }^{25}$ The final sociodemographic model included age, which was associated with a $14 \%$ decrease in the hazard of progressing to $\mathrm{CM}$ over 12 months for each change in age by 10 years (HR 0.86 [95\% CI 0.81-0.92]).

In the final sociodemographic model, all comorbidity classes had significantly elevated HRs for risk of progression to CM from EM, relative to the fewest comorbidities class (table 2). HRs for CM onset ranged from 5.34 (95\% CI 3.89-7.33; $p \leq$ 0.001 ) for the most comorbidities class to 1.53 (95\% CI $1.17-2.01 ; p<0.05$ ) for the respiratory class (table 2). The HR for CM onset was second highest in the class with a combination of respiratory and pain comorbidities (respiratory/pain class: HR 3.64 [95\% CI 2.67-4.98]).

Adjusting for headache covariates (e.g., headache-related disability [MIDAS], MSSS, allodynia, and medication overuse) independently resulted in attenuation of the relationship between comorbidity classes and progression to CM; however, the influence of each covariate on progression to $\mathrm{CM}$ relative to class 8 (fewest comorbidities) remained significant (table 3). For example, adjustment for headache-related disability (MIDAS) attenuated the HR for the most comorbidities class (from 5.34 [95\% CI 3.89-7.33] to 3.95 [95\% CI
2.85-5.48]), as did adjustment for medication overuse (from 5.34 [95\% CI 3.89-7.33] to 4.01 [95\% CI 2.92-5.51]). Adjustment for MSSS and allodynia also attenuated the HR for the most comorbidities class, although to a lesser degree than that observed with headache-related disability (MIDAS) and medication overuse (table 3 ).

In forward stepwise models, headache-related disability (MIDAS) came into the model first as it provided the most statistical improvement in model fit (table 4). Medication overuse was included next, followed by comorbidity class variable, allodynia, income, age, sex, and then MSSS. Only BMI and race were not added in the forward stepwise model. In the final forward stepwise model, all comorbidity classes were attenuated; however, class 1 (most comorbidities) retained the highest risk of progression to $\mathrm{CM}, 3$ times higher than the reference fewest comorbidities class (HR 3.01 [95\% CI 2.17-4.18]). The addition of age tended to increase the HR for the comorbidity classes; for example, the HR for most comorbidities increased to 3.02 (95\% CI 2.17-4.20) from 2.49 (95\% CI 1.83-3.39; table 4). Cardiovascular and pain classes lost statistical significance in the forward stepwise models, except after addition of age, where the HRs retained significance (cardiovascular 1.46 [95\% CI 1.00-2.13]; pain 1.48 [95\% CI 1.01-2.17]).

The results of the backward stepwise model converged on those of the forward stepwise model (table 5), with most comorbidities, respiratory /pain, and psychiatric classes having the highest risk of progression of all comorbidity classes.

\section{Discussion}

Discrete time analysis demonstrated that LCA-derived comorbidity classes of migraine, composed of naturally occurring constellations of comorbidities and concomitant conditions, were associated with different rates of risk of progression from EM to $\mathrm{CM}$ over 12 months, and results converged regardless of which modeling approach applied. When adjusting only for sociodemographic variables, all comorbidity classes were associated with a statistically significant risk of progression to CM. However, there were differences among comorbidity classes. For example, members of the most comorbidities class were approximately 5 times more likely to progress to $\mathrm{CM}$ than members of the fewest comorbidities class. The respiratory class was the least likely of the 7 comorbidity classes to progress to $\mathrm{CM}$ over time; however, members of this class were still 1.5 times more likely than members of the fewest comorbidities reference group to progress to $\mathrm{CM}$.

The addition of individual headache features in general, and headache-related disability (MIDAS) in particular, attenuated the risk of progression for all comorbidity classes, most prominently for the most comorbidities class. Nonetheless, even with the addition of all the headache features in the final step of the forward stepwise model, the HR for the progression to CM remained $>1$ for all comorbidity classes, with 
Table 1 Demographics and clinical characteristics at baseline of the comorbidity classes in the final analysis sample

\begin{tabular}{|c|c|c|c|c|c|c|c|c|c|}
\hline Characteristic $^{a}$ & $\begin{array}{l}\text { Class 1: most } \\
\text { comorbidities }\end{array}$ & $\begin{array}{l}\text { Class 2: respiratory/ } \\
\text { psychiatric }\end{array}$ & $\begin{array}{l}\text { Class 3: respiratory/ } \\
\text { pain }\end{array}$ & $\begin{array}{l}\text { Class 4: } \\
\text { respiratory }\end{array}$ & $\begin{array}{l}\text { Class 5: } \\
\text { psychiatric }\end{array}$ & $\begin{array}{l}\text { Class 6: } \\
\text { cardiovascular }\end{array}$ & $\begin{array}{l}\text { Class } \\
\text { 7: pain }\end{array}$ & $\begin{array}{l}\text { Class 8: fewest } \\
\text { comorbidities }\end{array}$ & Total \\
\hline \multicolumn{10}{|l|}{ Demographics } \\
\hline $\mathrm{N}(\%)$ & $409(4.7)$ & $928(10.7)$ & $655(7.6)$ & $1,719(19.9)$ & $650(7.5)$ & $724(8.4)$ & $\begin{array}{l}519 \\
(6.0)\end{array}$ & $3,054(35.3)$ & $\begin{array}{l}8,658 \\
(100)\end{array}$ \\
\hline Age, y, mean (SD) & $53.1(11.9)$ & $42.9(13.1)$ & $54.5(12.0)$ & $41.7(13.4)$ & $36.3(12.4)$ & $55(12.2)$ & $\begin{array}{l}48.6 \\
(13.7)\end{array}$ & $38(13.9)$ & $\begin{array}{l}43.2 \\
(14.7)\end{array}$ \\
\hline Women, n (\%) & $318(77.8)$ & $792(85.3)$ & $487(74.4)$ & $1,384(80.5)$ & $515(79.2)$ & 424 (58.6) & $\begin{array}{l}332 \\
(64.0)\end{array}$ & $2,244(73.5)$ & $\begin{array}{l}6,496 \\
(75.0)\end{array}$ \\
\hline Income $<\$ 50,000, \mathrm{n}(\%)$ & $218(53.3)$ & $398(42.9)$ & $217(33.4)$ & $615(36.0)$ & $309(47.8)$ & $230(32.3)$ & $\begin{array}{l}194 \\
(37.7)\end{array}$ & $1,216(40.1)$ & $\begin{array}{l}3,397 \\
(39.5)\end{array}$ \\
\hline White, n (\%) & $369(90.2)$ & $833(89.7)$ & $604(92.2)$ & $1,508(87.9)$ & $557(86.2)$ & $633(87.4)$ & $\begin{array}{l}427 \\
(82.8)\end{array}$ & $2,467(80.8)$ & $\begin{array}{l}7,398 \\
(85.7)\end{array}$ \\
\hline BMI, $\mathrm{kg} / \mathrm{m}^{2}$, mean (SD) & $32.4(8.4)$ & $29.2(7.9)$ & $30.9(7.7)$ & $28.0(7.1)$ & $27.6(8.0)$ & $32.0(7.3)$ & $\begin{array}{l}29.0 \\
(7.4)\end{array}$ & $27.2(7.0)$ & $\begin{array}{l}28.6 \\
(7.6)\end{array}$ \\
\hline
\end{tabular}

HA characteristics

\begin{tabular}{|c|c|c|c|c|c|c|c|c|c|}
\hline Monthly HA frequency, mean (SD) & $4.6(3.7)$ & $4.3(3.6)$ & $4.1(3.5)$ & $3.6(3.1)$ & $3.7(3.1)$ & $3.0(3.1)$ & $\begin{array}{l}3.7 \\
(3.3)\end{array}$ & $3.1(3.0)$ & $\begin{array}{l}3.5 \\
(3.2)\end{array}$ \\
\hline Monthly HA frequency, median (IQR) & $3.7(5.0)$ & $3.3(4.6)$ & $3.3(4.3)$ & $2.7(3.7)$ & $3.0(3.7)$ & $1.7(3.3)$ & $\begin{array}{l}2.7 \\
(4.0)\end{array}$ & $2.0(3.0)$ & $\begin{array}{l}2.3 \\
(4.0)\end{array}$ \\
\hline
\end{tabular}

MIDAS

\begin{tabular}{|c|c|c|c|c|c|c|c|c|c|}
\hline Median score & 14.0 & 10.0 & 7.0 & 6.0 & 8.0 & 3.0 & 6.0 & 4.0 & 6.0 \\
\hline Grade I, n (\%) & $118(28.9)$ & $316(34.1)$ & $276(42.1)$ & $775(45.1)$ & $262(40.3)$ & $440(60.9)$ & $\begin{array}{l}241 \\
(46.4)\end{array}$ & $1,688(55.3)$ & $\begin{array}{l}4,116 \\
(47.6)\end{array}$ \\
\hline Grade II, n (\%) & $57(14.0)$ & $181(19.5)$ & $128(19.5)$ & 355 (20.7) & $120(18.5)$ & 105 (14.5) & $\begin{array}{l}95 \\
(18.3)\end{array}$ & $538(17.6)$ & $\begin{array}{l}1,579 \\
(18.2)\end{array}$ \\
\hline Grade III, n (\%) & $82(20.1)$ & $211(22.7)$ & $123(18.8)$ & $309(18.0)$ & $130(20.0)$ & 99 (13.7) & $\begin{array}{l}103 \\
(19.8)\end{array}$ & $450(14.7)$ & $\begin{array}{l}1,507 \\
(17.4)\end{array}$ \\
\hline Grade IV, n (\%) & $151(37.0)$ & $220(23.7)$ & 128 (19.5) & $279(16.2)$ & $138(21.2)$ & 79 (10.9) & $\begin{array}{l}80 \\
(15.4)\end{array}$ & $378(12.4)$ & $\begin{array}{l}1,453 \\
(16.8)\end{array}$ \\
\hline Allodynia, n (\%) & $246(60.1)$ & $522(56.3)$ & $341(52.1)$ & $805(46.8)$ & 305 (46.9) & $261(36.0)$ & $\begin{array}{l}246 \\
(47.4)\end{array}$ & $1,118(36.6)$ & $\begin{array}{l}3,844 \\
(44.4)\end{array}$ \\
\hline MSSS, mean (SD) & $15.8(3.2)$ & $16.0(3.2)$ & $15.6(3.1)$ & $15.3(3.2)$ & $15.7(3.1)$ & $14.6(3.1)$ & $\begin{array}{l}15.3 \\
(3.2)\end{array}$ & $14.9(3.2)$ & $\begin{array}{l}15.3 \\
(3.2)\end{array}$ \\
\hline
\end{tabular}


the lowest HR never falling below 1.41 (95\% CI 0.96-2.05, cardiovascular class). This suggests that the effect of comorbidity class membership on progression to $\mathrm{CM}$ is moderately large, and relatively independent of headache characteristics.

We did not adjust for headache day frequency specifically; however, the observation that the addition of headacherelated disability (MIDAS) to the model attenuates the HRs for many of the comorbidity classes is likely due, at least in part, to the correlation between headache days and total MIDAS score. ${ }^{26}$ Importantly, the addition of headacherelated disability (MIDAS) and therefore partially adjusting for underlying headache days did not fully explain the association among comorbidity classes and risk of progression to CM. Of note, although the HR for MIDAS per 10-point change is only 1.11, this represents risk of progression to CM for each 10-point change in MIDAS. For a 20-point change in MIDAS, the HR would be 1.22; for a 40-point change in MIDAS, the HR would be 1.49. Indeed, headache-related disability (MIDAS) as an individual covariate explained more variability in the progression to $\mathrm{CM}$ than any other covariate, and was the first covariate entered into the forward stepwise model. Similarly, the HR for age was based on risk of progression to CM for each 10-year change in age, while the HR for MSSS and BMI was based on risk of progression to CM for each 1-point change in MSSS or BMI. In contrast, allodynia and medication overuse were modeled as binary variables and HRs represent increased risk of progression for those with vs without allodynia or with vs without medication overuse.

Others have reported an association between allodynia and certain subgroups of migraine. ${ }^{6,27}$ Given the association between allodynia and central sensitization, ${ }^{28}$ it might be expected that allodynia would attenuate HRs for members of classes with pain comorbidities (i.e., respiratory/pain and pain classes). While allodynia attenuated the HR, to a degree, the magnitude of the effect was relatively uniform across comorbidity classes. Medication overuse, like headache-related disability (MIDAS), was a powerful predictor of progression (HR 4.06 [95\% CI 3.41-4.84]), confirming the findings of others. ${ }^{29-31}$ The addition of medication overuse attenuated the HR for the most comorbidities and respiratory classes in particular. It is unclear from our analysis whether medication overuse is acting as a confounder (medication overuse is associated with comorbidity class and risk of progression) or a mediator (persons in particular comorbidity classes, for example the psychiatric class, tend to overuse medication, which in turns increases the risk of progression). We did not explore the effect of the type of medication being overused and the risk of progression for the subclasses of migraine; this could be usefully explored in the future.

It is interesting to note that when pain and respiratory conditions occurred in relative isolation, they had relatively 
Table 2 Discrete time hazard to chronic migraine onset: reference group fewest comorbidities class ( $\mathrm{n}=3,054$ [fewest comorbidities class]/8,658 [total], 35.3\%)

\begin{tabular}{|c|c|c|c|}
\hline Variable & $\begin{array}{l}\text { Frequency, } \\
\mathrm{n}(\%)\end{array}$ & $\begin{array}{l}\text { Demographic model, hazard ratio } \\
(95 \% \mathrm{Cl})\end{array}$ & $\begin{array}{l}\text { Demographic model (excluding race), hazard ratio } \\
(95 \% \mathrm{Cl})\end{array}$ \\
\hline Sex & & $1.20(0.99-1.45)$ & $1.19(0.99-1.44)$ \\
\hline Age, per 10 years of age & & $0.86^{\mathrm{a}}(0.81-0.92)$ & $0.86^{a}(0.81-0.92)$ \\
\hline Race: white & & $1.05(0.82-1.35)$ & Trimmed \\
\hline Income: $\geq \$ 50,000$ & & $0.74^{\mathrm{a}}(0.63-0.88)$ & $0.73^{\mathrm{a}}(0.62-0.87)$ \\
\hline \multicolumn{4}{|l|}{ LCA class } \\
\hline Most comorbidities & $409(4.7)$ & $5.41^{a}(3.94-7.44)$ & $5.34^{\mathrm{a}}(3.89-7.33)$ \\
\hline Respiratory/psychiatric & $928(10.7)$ & $2.43^{\mathrm{a}}(1.82-3.25)$ & $2.40^{\mathrm{a}}(1.80-3.20)$ \\
\hline Respiratory/pain & $655(7.6)$ & $3.67^{\mathrm{a}}(2.68-5.02)$ & $3.64^{a}(2.67-4.98)$ \\
\hline Respiratory & $1,719(19.9)$ & $1.55^{\mathrm{a}}(1.18-2.03)$ & $1.53^{\mathrm{b}}(1.17-2.01)$ \\
\hline Psychiatric & $650(7.5)$ & $2.36^{\mathrm{a}}(1.73-3.23)$ & $2.41^{a}(1.77-3.28)$ \\
\hline Cardiovascular & $724(8.4)$ & $1.63^{b}(1.11-2.39)$ & $1.62^{\mathrm{b}}(1.10-2.37)$ \\
\hline Pain & $519(6.0)$ & $1.97^{\mathrm{a}}(1.35-2.88)$ & $1.93^{\mathrm{a}}(1.32-2.82)$ \\
\hline $\begin{array}{l}\text { BMI, baseline, per point change } \\
\text { in BMI }\end{array}$ & & $1.01^{\mathrm{b}}(1.00-1.02)$ & $1.01^{\mathrm{b}}(1.00-1.02)$ \\
\hline
\end{tabular}

Abbreviations: $\mathrm{BMI}=$ body mass index; $\mathrm{Cl}=$ confidence interval; $\mathrm{LCA}=$ latent class analysis.

a $p \leq 0.001$, compared with the fewest comorbidities class.

${ }^{\mathrm{b}} p \leq 0.05$, compared with the fewest comorbidities class.

low HRs (approximately 1.4) for progression to CM in forward stepwise models compared with the other subgroups. When these comorbidities occurred with other conditions, they were associated with higher HRs for progression to CM. For example, the HR for the respiratory/psychiatric subgroup was 1.87 (95\% CI 1.40-2.50) and that for the respiratory/pain subgroup was 2.57 (95\% CI 1.88-3.51). This suggests that when certain comorbidities occur together, the risk for progression to $\mathrm{CM}$ is increased.

As discussed previously, the rationale for the apparent grouping of migraine based on comorbidities could be variable. $^{7}$ It is possible that some of the comorbidities are actually symptoms of migraine per se and not separate conditions, while others may share underlying pathophysiologic mechanisms with migraine.

\section{Study strengths and limitations}

An overview of limitations of the primary CaMEO Study has been reported previously, including relatively low response rates to the initial invitation resulting in potential selection bias and all data being self-reported. ${ }^{7,16}$ Despite these potential limitations, the web-based longitudinal design enabled the collection of comprehensive information on respondents with migraine over 12 months, and for this analysis there were substantial numbers of individuals in each comorbidity class. Nonresponse bias for the CaMEO respondents was assessed through comparison of demographics and disease severity between respondents and nonrespondents using data from a follow-up survey to nonrespondents. ${ }^{16}$ Characteristics were found to be similar across respondents and nonrespondents; however, the percentage of individuals with $\mathrm{CM}$ and those with headache in the last 30 or 90 days was higher among respondents than nonrespondents. Furthermore, the low response rate to the nonrespondents' survey leaves open the possibility of nonrespondent bias. However, the baseline demographics and headache characteristics of the CaMEO population and the AMPP population were similar, ${ }^{23} \mathrm{dem}-$ onstrating that, since the AMPP Study sample, with a response rate of $64.8 \%$, is considered representative of the US population with migraine, the CaMEO data could also be generalizable to the US population with migraine. Another limitation is the relatively brief duration of follow-up.

It should also be noted that we elected to include BMI as a continuous variable rather than dichotomizing it in 2 groups: obese and less than obese. Generally, the continuous variable BMI provides a more sensitive adjustment because information is coarsened when it is dichotomized. It is possible that including BMI as a continuous variable may have resulted in missing a potential effect of obesity. One large population study showed that BMI was not associated with migraine prevalence after adjustments for age, race, and education; in contrast, increasing BMI, using normal weight as a reference, was associated with high attack frequency and other clinical features of 
Table 3 Five separate models for discrete time hazard to chronic migraine onset in comorbidity classes of migraine in individuals with episodic migraine at baseline

\begin{tabular}{|c|c|c|c|c|c|}
\hline \multirow[b]{2}{*}{ Variable } & \multicolumn{5}{|l|}{ Hazard ratio $(95 \% \mathrm{Cl})$} \\
\hline & $\begin{array}{l}\text { Demographic model } \\
\text { (excluding race) }\end{array}$ & $\begin{array}{l}\text { Including MIDAS } \\
\text { (10-point change) }\end{array}$ & $\begin{array}{l}\text { Including } \\
\text { MSSS }\end{array}$ & $\begin{array}{l}\text { Including } \\
\text { allodynia }\end{array}$ & $\begin{array}{l}\text { Including medication } \\
\text { overuse }\end{array}$ \\
\hline Sex & $1.19(0.99-1.44)$ & $1.20(0.99-1.46)$ & $\begin{array}{l}1.28^{\mathrm{b}} \\
(1.06-1.55)\end{array}$ & $\begin{array}{l}1.30^{\mathrm{b}} \\
(1.08-1.58)\end{array}$ & $1.22^{\mathrm{b}}(1.01-1.48)$ \\
\hline Age & $0.86^{\mathrm{a}}(0.81-0.92)$ & $0.89^{\mathrm{a}}(0.84-0.95)$ & $\begin{array}{l}0.88^{\mathrm{a}} \\
(0.82-0.94)\end{array}$ & $\begin{array}{l}0.88^{\mathrm{a}} \\
(0.82-0.94)\end{array}$ & $0.87^{\mathrm{a}}(0.81-0.92)$ \\
\hline Income: $>\$ 50,000$ & $0.73^{a}(0.62-0.87)$ & $0.74^{\mathrm{a}}(0.62-0.87)$ & $\begin{array}{l}0.74^{\mathrm{a}} \\
(0.62-0.87)\end{array}$ & $\begin{array}{l}0.74^{\mathrm{a}} \\
(0.63-0.88)\end{array}$ & $0.71^{\mathrm{a}}(0.60-0.84)$ \\
\hline \multicolumn{6}{|l|}{ LCA class } \\
\hline Most comorbidities & $5.34^{\mathrm{a}}(3.89-7.33)$ & $3.95^{\mathrm{a}}(2.85-5.48)$ & $\begin{array}{l}4.90^{\mathrm{a}} \\
(3.57-6.74)\end{array}$ & $\begin{array}{l}4.57^{\mathrm{a}} \\
(3.32-6.29)\end{array}$ & $4.01^{\mathrm{a}}(2.92-5.51)$ \\
\hline $\begin{array}{l}\text { Respiratory/psychiatric } \\
\text { comorbidities }\end{array}$ & $2.40^{\mathrm{a}}(1.80-3.20)$ & $2.22^{\mathrm{a}}(1.67-2.96)$ & $\begin{array}{l}2.23^{\mathrm{a}} \\
(1.67-2.97)\end{array}$ & $\begin{array}{l}2.16^{\mathrm{a}} \\
(1.62-2.88)\end{array}$ & $2.12^{\mathrm{a}}(1.59-2.83)$ \\
\hline $\begin{array}{l}\text { Respiratory/pain } \\
\text { comorbidities }\end{array}$ & $3.64^{\mathrm{a}}(2.67-4.98)$ & $3.41^{\mathrm{a}}(2.50-4.65)$ & $\begin{array}{l}3.38^{\mathrm{a}} \\
(2.47-4.63)\end{array}$ & $\begin{array}{l}3.24^{a} \\
(2.37-4.43)\end{array}$ & $2.93^{\mathrm{a}}(2.15-4.00)$ \\
\hline Respiratory comorbidities & $1.53^{\mathrm{b}}(1.17-2.01)$ & $1.50^{\mathrm{b}}(1.14-1.96)$ & $\begin{array}{l}1.48^{b} \\
(1.13-1.93)\end{array}$ & $\begin{array}{l}1.43^{b} \\
(1.09-1.87)\end{array}$ & $1.50^{\mathrm{b}}(1.15-1.96)$ \\
\hline Psychiatric comorbidities & $2.41^{\mathrm{a}}(1.77-3.28)$ & $2.33^{\mathrm{a}}(1.72-3.17)$ & $\begin{array}{l}2.30^{a} \\
(1.69-3.12)\end{array}$ & $\begin{array}{l}2.32^{a} \\
(1.71-3.15)\end{array}$ & $2.22^{\mathrm{a}}(1.63-3.02)$ \\
\hline $\begin{array}{l}\text { Cardiovascular } \\
\text { comorbidities }\end{array}$ & $1.62^{\mathrm{b}}(1.10-2.37)$ & $1.49^{\mathrm{b}}(1.02-2.17)$ & $\begin{array}{l}1.61^{\mathrm{b}} \\
(1.10-2.35)\end{array}$ & $\begin{array}{l}1.55^{\mathrm{b}} \\
(1.06-2.27)\end{array}$ & $1.57^{\mathrm{b}}(1.07-2.29)$ \\
\hline Pain & $1.93^{\mathrm{a}}(1.32-2.83)$ & $1.62^{\mathrm{b}}(1.10-2.38)$ & $\begin{array}{l}1.85^{\mathrm{b}} \\
(1.26-2.70)\end{array}$ & $\begin{array}{l}1.76^{\mathrm{b}} \\
(1.21-2.58)\end{array}$ & $1.66^{\mathrm{b}}(1.14-2.43)$ \\
\hline BMI, baseline & $1.01^{\mathrm{b}}(1.00-1.02)$ & Trimmed & $\begin{array}{l}1.01 \\
(1.00-1.02)\end{array}$ & $\begin{array}{l}1.01^{\mathrm{b}} \\
(1.00-1.02)\end{array}$ & Trimmed \\
\hline $\begin{array}{l}\text { Covariate (see column } \\
\text { header) }\end{array}$ & NA & $1.11^{\mathrm{a}}(1.09-1.13)$ & $\begin{array}{l}1.08^{\mathrm{a}} \\
(1.05-1.11)\end{array}$ & $\begin{array}{l}1.77^{\mathrm{a}} \\
(1.49-2.10)\end{array}$ & $4.06^{a}(3.41-4.84)$ \\
\hline
\end{tabular}

Abbreviations: $\mathrm{BMI}=$ body mass index; $\mathrm{Cl}$ = confidence interval; LCA = latent class analysis; MIDAS = Migraine Disability Assessment Scale; MSSS = Migraine Symptom Severity Scale.

Five separate models, each including the indicated headache characteristic covariate plus demographics; age (per 10-year group); BMI (per 1-point change in $\mathrm{kg} / \mathrm{m}^{2}$ ), MIDAS (per 10-point change in score), and MSSS (per 1-point change in score) were modeled as continuous variables; sex, medication overuse, allodynia ( $<3$ vs $\geq 3)$, and income $(<\$ 50,000$ vs $\geq \$ 50,000)$ were modeled as binary variables.

${ }^{\text {a }} p \leq 0.001$.

b $p<0.05$.

migraine. ${ }^{32}$ The greatest effects tended to occur in those with a BMI of $30-34.9 \mathrm{~kg} / \mathrm{m}^{2}$ (obese) or a BMI $\geq 35 \mathrm{~kg} / \mathrm{m}^{2}$ (morbidly obese). A more recent meta-analysis of 12 studies indicated that both obesity (BMI $\geq 30$ ) and underweight (BMI $<18.5)$ were associated with the risk of migraine. ${ }^{33}$

There are a number of additional limitations. It should be noted that we relied on self-reported medical diagnosis of comorbidities and concomitant conditions, which could lead to either underascertainment or overascertainment of specific comorbidities. ${ }^{7,34}$ A more robust approach might have relied on systematic diagnostic assessments, an important step for a future study. In addition, a form of Berkson bias could influence our results. Individuals with more severe migraine may have visited their health professional more frequently and, as a result, might have been more likely to have been diagnosed with a concomitant condition and fall into the most comorbidities class. In this circumstance, severe migraine and not the comorbidity class could have been the driver of progression. However, for most of the comorbid subgroups, risk of progression remained elevated after adjustment for measures of headache severity.

Second, LCA identified comorbid subgroups with overlapping comorbidity profiles; for example, the respiratory/psychiatric and respiratory/pain classes. This requires cautious interpretation. Our results do not reflect the effect of a comorbidity per se on disease progression, but rather the effect of comorbidity class membership on clinical course of disease.

Third, we have adjusted for a number of headache characteristics assuming that they may act as confounders and explain the change in risk of progression to $\mathrm{CM}$ in the subgroups. As noted above, some of these features may be 
Table 4 Forward stepwise model for the discrete time hazard to chronic migraine onset in comorbidity classes of migraine in individuals with episodic migraine at baseline

\begin{tabular}{|c|c|c|c|c|c|c|c|c|}
\hline \multirow[b]{2}{*}{ Variable } & \multicolumn{8}{|c|}{ Hazard ratio $(95 \% \mathrm{Cl})$} \\
\hline & Step 1 & Step 2 & Step 3 & Step 4 & Step 5 & Step 6 & Step 7 & Step 8 \\
\hline Sex & & & & & & & $\begin{array}{l}1.31 \\
(1.08-1.58)^{a}\end{array}$ & $\begin{array}{l}1.36^{\mathrm{b}} \\
(1.12-1.65)\end{array}$ \\
\hline $\begin{array}{l}\text { Age (10-year age } \\
\text { grouping) }\end{array}$ & & & & & & $\begin{array}{l}0.90 \\
(0.84-0.96)^{a}\end{array}$ & $\begin{array}{l}0.90 \\
(0.84-0.96)\end{array}$ & $\begin{array}{l}0.90^{\mathrm{b}} \\
(0.85-0.96)\end{array}$ \\
\hline Income: $\geq \$ 50,000$ & & & & & $\begin{array}{l}0.73 \\
(0.61-0.86)^{a}\end{array}$ & $\begin{array}{l}0.76 \\
(0.64-0.90)\end{array}$ & $\begin{array}{l}0.75 \\
(0.63-0.89)\end{array}$ & $\begin{array}{l}0.75^{c} \\
(0.63-0.89)\end{array}$ \\
\hline \multicolumn{9}{|l|}{ LCA class } \\
\hline $\begin{array}{l}\text { Most } \\
\text { comorbidities }\end{array}$ & & & $\begin{array}{l}2.80 \\
(2.06-3.80)^{a}\end{array}$ & $\begin{array}{l}2.59 \\
(1.91-3.53)\end{array}$ & $\begin{array}{l}2.49 \\
(1.83-3.39)\end{array}$ & $\begin{array}{l}3.02 \\
(2.17-4.20)\end{array}$ & $\begin{array}{l}3.07 \\
(2.21-4.27)\end{array}$ & $\begin{array}{l}3.01^{\mathrm{c}} \\
(2.17-4.18)\end{array}$ \\
\hline $\begin{array}{r}\text { Respiratory/ } \\
\text { psychiatric }\end{array}$ & & & $\begin{array}{l}1.86 \\
(1.39-2.47)^{\mathrm{a}}\end{array}$ & $\begin{array}{l}1.75 \\
(1.31-2.33)\end{array}$ & $\begin{array}{l}1.75 \\
(1.32-2.34)\end{array}$ & $\begin{array}{l}1.87 \\
(1.40-2.49)\end{array}$ & $\begin{array}{l}1.93 \\
(1.44-2.58)\end{array}$ & $\begin{array}{l}1.87^{c} \\
(1.40-2.50)\end{array}$ \\
\hline Respiratory/pain & & & $\begin{array}{l}2.25 \\
(1.68-3.02)^{a}\end{array}$ & $\begin{array}{l}2.13 \\
(1.59-2.86)\end{array}$ & $\begin{array}{l}2.21 \\
(1.64-2.96)\end{array}$ & $\begin{array}{l}2.61 \\
(1.91-3.57)\end{array}$ & $\begin{array}{l}2.63 \\
(1.92-3.60)\end{array}$ & $\begin{array}{l}2.57^{c} \\
(1.88-3.51)\end{array}$ \\
\hline Respiratory & & & $\begin{array}{l}1.40 \\
(1.07-1.82)^{a}\end{array}$ & $\begin{array}{l}1.33 \\
(1.01-1.74)\end{array}$ & $\begin{array}{l}1.35 \\
(1.03-1.76)\end{array}$ & $\begin{array}{l}1.40 \\
(1.07-1.83)\end{array}$ & $\begin{array}{l}1.42 \\
(1.09-1.87)\end{array}$ & $\begin{array}{l}1.41^{\mathrm{b}} \\
(1.07-1.84)\end{array}$ \\
\hline Psychiatric & & & $\begin{array}{l}2.22 \\
(1.63-3.03)^{a}\end{array}$ & $\begin{array}{l}2.15 \\
(1.58-2.94)\end{array}$ & $\begin{array}{l}2.10 \\
(1.54-2.87)\end{array}$ & $\begin{array}{l}2.09 \\
(1.53-2.85)\end{array}$ & $\begin{array}{l}2.12 \\
(1.55-2.89)\end{array}$ & $\begin{array}{l}2.07^{c} \\
(1.52-2.83)\end{array}$ \\
\hline Cardiovascular & & & $\begin{array}{l}1.21 \\
(0.84-1.74)^{a}\end{array}$ & $\begin{array}{l}1.21 \\
(0.84-1.74)\end{array}$ & $\begin{array}{l}1.25 \\
(0.87-1.80)\end{array}$ & $\begin{array}{l}1.46 \\
(1.00-2.13)\end{array}$ & $\begin{array}{l}1.40 \\
(0.96-2.04)\end{array}$ & $\begin{array}{l}1.41 \\
(0.96-2.05)\end{array}$ \\
\hline Pain & & & $\begin{array}{l}1.35 \\
(0.93-1.97)^{\mathrm{a}}\end{array}$ & $\begin{array}{l}1.30 \\
(0.89-1.90)\end{array}$ & $\begin{array}{l}1.32 \\
(0.91-1.93)\end{array}$ & $\begin{array}{l}1.48 \\
(1.01-2.17)\end{array}$ & $\begin{array}{l}1.42 \\
(0.96-2.09)\end{array}$ & $\begin{array}{l}1.41 \\
(0.96-2.07)\end{array}$ \\
\hline $\begin{array}{l}\text { MIDAS (10-point } \\
\text { change) }\end{array}$ & $\begin{array}{l}1.13 \\
(1.11-1.14)^{\mathrm{a}}\end{array}$ & $\begin{array}{l}1.09 \\
(1.07-1.10)\end{array}$ & $\begin{array}{l}1.08 \\
(1.07-1.10)\end{array}$ & $\begin{array}{l}1.08 \\
(1.06-1.09)\end{array}$ & $\begin{array}{l}1.07 \\
(1.06-1.09)\end{array}$ & $\begin{array}{l}1.07 \\
(1.05-1.09)\end{array}$ & $\begin{array}{l}1.07 \\
(1.05-1.09)\end{array}$ & $\begin{array}{l}1.07^{c} \\
(1.05-1.09)\end{array}$ \\
\hline MSSS & & & & & & & & $\begin{array}{l}1.04^{\mathrm{b}} \\
(1.01-1.07)^{\mathrm{a}}\end{array}$ \\
\hline Allodynia & & & & $\begin{array}{l}1.50 \\
(1.26-1.78)^{\mathrm{a}}\end{array}$ & $\begin{array}{l}1.47 \\
(1.24-1.75)\end{array}$ & $\begin{array}{l}1.44 \\
(1.21-1.71)\end{array}$ & $\begin{array}{l}1.48 \\
(1.24-1.76)\end{array}$ & $\begin{array}{l}1.41^{\mathrm{c}} \\
(1.18-1.69)\end{array}$ \\
\hline $\begin{array}{c}\text { Medication } \\
\text { overuse }\end{array}$ & & $\begin{array}{l}3.75 \\
(3.13-4.50)^{\mathrm{a}}\end{array}$ & $\begin{array}{l}3.34 \\
(2.78-4.02)\end{array}$ & $\begin{array}{l}3.23 \\
(2.68-3.88)\end{array}$ & $\begin{array}{l}3.26 \\
(2.71-3.92)\end{array}$ & $\begin{array}{l}3.28 \\
(2.72-3.94)\end{array}$ & $\begin{array}{l}3.28 \\
(2.73-3.95)\end{array}$ & $\begin{array}{l}3.22^{c} \\
(2.68-3.88)\end{array}$ \\
\hline
\end{tabular}

Abbreviations: $\mathrm{Cl}$ = confidence interval; LCA = latent class analysis; MIDAS = Migraine Disability Assessment; MSSS = Migraine Symptom Severity Scale. Where no data are provided in a cell, that covariate has not been added by that step of the forward stepwise model; for modeling of covariates, see table 3. ${ }^{a}$ Covariates added in that step of the stepwise model.

${ }^{\mathrm{b}} p \leq 0.001$, compared with the fewest comorbidities class.

c $p \leq 0.05$, compared with the fewest comorbidities class.

mediators; they may be in the causal pathway linking the comorbid subgroup to disease progression. ${ }^{35}$ In addition, we cannot exclude the possibility that there may be potential mediators and confounders we did not include.

Fourth, as previously reported, we defined our subgroups of migraines based on a cross-section of self-reported comorbidities rather than on other markers of disease. ${ }^{7}$ We could have selected other measures for identifying subgroups including migraine symptom profiles, ${ }^{36}$ measures of brain structure, ${ }^{5,6}$ or treatment response. ${ }^{3,36}$ Ultimately, subgroups of migraine could also be defined based on longitudinal data using latent trajectory modeling, and the effect of class membership on the treatment response, neuroimaging, and biologic markers could be further explored.
Finally, we only considered progression from EM to CM and not fluctuation between EM and CM. The fact that patients alternate between periods of EM and CM is well-recognized $^{37}$; the effect of subgroups of migraine on fluctuation between EM and CM is worthy of further exploration.

Despite the limitations outlined above, our results are an important illustration that we can define subgroups of migraine based on cross-sectional comorbidity profiles, and that membership of these subgroups predicts disease progression over time.

By identifying comorbidity classes in migraine and observing their relationship with changes in disease over time, we hope to understand more about the underlying heterogeneity of migraine and identify the genetic and biologic features for each 
Table 5 Comparison of the results of backward and forward stepwise models

\begin{tabular}{|c|c|c|c|c|}
\hline \multirow[b]{2}{*}{ Variable } & \multicolumn{2}{|l|}{ Backward model } & \multicolumn{2}{|l|}{ Forward model } \\
\hline & All covariates & Remove race & Remove BMI & Step 8: final step \\
\hline Sex & $1.37^{\mathrm{a}}(1.12-1.66)$ & $1.37^{a}(1.12-1.66)$ & $1.36^{\mathrm{a}}(1.12-1.65)$ & $1.36^{\mathrm{a}}(1.12-1.65)$ \\
\hline Age (10-year age grouping) & $0.90^{a}(0.84-0.96)$ & $0.90^{\mathrm{a}}(0.84-0.96)$ & $0.90^{\mathrm{a}}(0.85-0.96)$ & $0.90^{a}(0.85-0.96)$ \\
\hline Race & $1.01(0.79-1.29)$ & & & \\
\hline Income: $\geq \$ 50,000$ & $0.76^{a}(0.64-0.90)$ & $0.76^{\mathrm{a}}(0.64-0.90)$ & $0.75^{\mathrm{b}}(0.63-0.89)$ & $0.75^{\mathrm{b}}(0.63-0.89)$ \\
\hline \multicolumn{5}{|l|}{ LCA class } \\
\hline Most comorbidities & $2.92^{\mathrm{b}}(2.10-4.08)$ & $2.92^{\mathrm{b}}(2.10-4.08)$ & $3.01^{\mathrm{b}}(2.17-4.18)$ & $3.01^{\mathrm{b}}(2.17-4.18)$ \\
\hline Respiratory/psychiatric & $1.85^{\mathrm{b}}(1.38-2.48)$ & $1.85^{\mathrm{b}}(1.38-2.47)$ & $1.87^{\mathrm{b}}(1.40-2.50)$ & $1.87^{\mathrm{b}}(1.40-2.50)$ \\
\hline Respiratory/pain & $2.52^{\mathrm{b}}(1.84-3.45)$ & $2.52^{\mathrm{b}}(1.84-3.45)$ & $2.57^{\mathrm{b}}(1.88-3.51)$ & $2.57^{\mathrm{b}}(1.88-3.51)$ \\
\hline Respiratory & $1.40^{a}(1.07-1.83)$ & $1.40^{\mathrm{a}}(1.07-1.83)$ & $1.41^{\mathrm{a}}(1.07-1.84)$ & $1.41^{\mathrm{a}}(1.07-1.84)$ \\
\hline Psychiatric & $2.06^{\mathrm{b}}(1.51-2.82)$ & $2.06^{\mathrm{b}}(1.51-2.82)$ & $2.07^{\mathrm{b}}(1.52-2.83)$ & $2.07^{\mathrm{b}}(1.52-2.83)$ \\
\hline Cardiovascular & $1.37(0.94-2.00)$ & $1.37(0.94-2.00)$ & $1.41(0.96-2.05)$ & $1.41(0.96-2.05)$ \\
\hline Pain & $1.40(0.95-2.05)$ & $1.40(0.95-2.05)$ & $1.41(0.96-2.07)$ & $1.41(0.96-2.07)$ \\
\hline BMI & $1.01(1.00-1.02)$ & $1.01(1.00-1.02)$ & & \\
\hline MIDAS (10-point grouping) & $1.07^{\mathrm{b}}(1.05-1.09)$ & $1.07^{\mathrm{b}}(1.05-109)$ & $1.07^{\mathrm{b}}(1.05-1.09)$ & $1.07^{\mathrm{b}}(1.05-1.09)$ \\
\hline MSSS & $1.04^{\mathrm{a}}(1.01-1.07)$ & $1.04^{\mathrm{a}}(1.01-1.07)$ & $1.04^{\mathrm{a}}(1.01-1.07)$ & $1.04^{a}(1.01-1.07)$ \\
\hline Allodynia & $1.42^{\mathrm{b}}(1.19-1.69)$ & $1.42^{\mathrm{b}}(1.19-1.69)$ & $1.41^{\mathrm{b}}(1.18-1.69)$ & $1.41^{\mathrm{b}}(1.18-1.69)$ \\
\hline Medication overuse & $3.21^{\mathrm{b}}(2.67-3.87)$ & $3.21^{\mathrm{b}}(2.67-3.87)$ & $3.22^{\mathrm{b}}(2.68-3.88)$ & $3.22^{\mathrm{b}}(2.68-3.88)$ \\
\hline
\end{tabular}

Abbreviations: BMI = body mass index; LCA = latent class analysis; MIDAS = Migraine Disability Assessment; MSSS = Migraine Symptom Severity Scale.

Values are hazard ratio (95\% confidence interval).

a $p \leq 0.001$, compared with the fewest comorbidities class.

b $p \leq 0.05$, compared with the fewest comorbidities class.

different class. The identification of homogeneous subgroups of migraine will most certainly be an iterative process; this analysis forms an important early step in identification of homogeneous subclasses of migraine. The clinical importance of subgroups we have identified is demonstrated by the differences among classes in the risk of progression to CM over time. The relationship of comorbidity group to $\mathrm{CM}$ onset remained after adjusting for indicators of migraine severity and other potential confounders (e.g., headache-related disability [MIDAS], MSSS, allodynia, and medication overuse). When these were added to the model to explain some of the observed differences, comorbidity classes still differed in their risk of progression to CM, suggesting that there are underlying biologic or genetic similarities linking members of each class. As a next step, external validation of comorbidity classes will be undertaken to determine whether we can predict treatment responses to different types of treatment based on comorbidity class.

\section{Acknowledgment}

Writing and editorial support was provided by Lisa Feder, $\mathrm{PhD}$, of Peloton Advantage, LLC, an OPEN Health company (Parsippany, NJ), and Gerard P. Johnson, $\mathrm{PhD}$, of $\mathrm{CHC}$ Group, LLC (North Wales, PA), an ICON plc company, and was funded by Allergan plc, Dublin, Ireland.

\section{Study funding}

This study was funded by Allergan plc, Dublin, Ireland. The Article Processing Charge was funded by Allergan plc.

\section{Disclosure}

R. Lipton serves on the editorial boards of Neurology ${ }^{\circledR}$ and Cephalalgia and as senior advisor to Headache; has received research support from the NIH; receives support from the Migraine Research Foundation and the National Headache Foundation; has reviewed for the NIA and NINDS; serves as consultant, advisory board member, or has received honoraria from Alder, Allergan, Amgen, Autonomic Technologies, Avanir, Biohaven, Biovision, Boston Scientific, Dr. Reddy's Laboratories, Electrocore, Eli Lilly, eNeura Therapeutics, GlaxoSmithKline, Merck, Novartis, Pernix, Pfizer, Supernus, Teva, Vector, and Vedanta; receives royalties from Wolff's Headache (8th Edition, Oxford University Press), Informa, and Wiley; and holds stock options in eNeura Therapeutics and Biohaven. K. Fanning is an employee of Vedanta Research, which has received support funded by Allergan, Amgen, Promius, Eli Lilly, GlaxoSmithKline, and Merck \& Co., Inc., via grants to the National Headache Foundation. D. Buse has received grant support and honoraria from Allergan, Avanir, 
Amgen, Eli Lilly and Company, Teva, and Promius; and is on the editorial board of Current Pain and Headache Reports. V. Martin has been a consultant for Allergan, Amgen, Alder, Avanir, Biohaven, Promius, Supernus, Eli Lilly, and Teva, and a speaker for Allergan, Amgen, Avanir, Eli Lilly, Depomed, and Pfizer. L. Hohaia is an employee of CHC Group, LLC, an ICON plc company, which has received funding from Allergan for manuscript development. A. Manack Adams is a full-time employee of Allergan plc and owns stock in the company. M. Reed is Managing Director of Vedanta Research, which has received research funding from Allergan, Amgen, Promius, Eli Lilly, GlaxoSmithKline, and Merck \& Co., Inc., via grants to the National Headache Foundation. Vedanta Research has received funding directly from Allergan for work on the CaMEO Study. P. Goadsby reports personal fees from Alder Biopharmaceuticals, Autonomic Technologies Inc., Biohaven Pharmaceuticals Inc., Dr. Reddy's Laboratories, Electrocore LLC, Novartis, Scion, Teva Pharmaceuticals, Trigemina Inc., MedicoLegal work, Massachusetts Medical Society, Up-toDate, Oxford University Press, and Wolters Kluwer outside the submitted work; grants and personal fees from Amgen, Eli Lilly and Company, and eNeura Inc.; and has a patent for magnetic stimulation for headache assigned to eNeura without fee. Go to Neurology.org/ $\mathrm{N}$ for full disclosures.

\section{Publication history}

Received by Neurology January 10, 2019. Accepted in final form June 26, 2019.

Appendix Author contributions

\begin{tabular}{|c|c|c|c|}
\hline Name & Location & Role & Contribution \\
\hline $\begin{array}{l}\text { Richard } \\
\text { B. Lipton, } \\
\text { MD }\end{array}$ & $\begin{array}{l}\text { Albert Einstein College } \\
\text { of Medicine, Bronx, NY }\end{array}$ & Author & $\begin{array}{l}\text { Substantial contributions } \\
\text { to the study conception } \\
\text { and design, analysis and } \\
\text { interpretation of the data } \\
\text { for the work, revised the } \\
\text { manuscript for } \\
\text { intellectual content, and } \\
\text { approved the final } \\
\text { manuscript for } \\
\text { submission }\end{array}$ \\
\hline
\end{tabular}

\begin{tabular}{|c|c|c|c|}
\hline $\begin{array}{l}\text { Kristina } \\
\text { M. } \\
\text { Fanning, } \\
\text { PhD }\end{array}$ & $\begin{array}{l}\text { Vedanta Research, } \\
\text { Chapel Hill, NC }\end{array}$ & Author & $\begin{array}{l}\text { Substantial contributions } \\
\text { to the study design, } \\
\text { acquisition, analysis and } \\
\text { interpretation of the data } \\
\text { for the work, revised the } \\
\text { manuscript for } \\
\text { intellectual content, and } \\
\text { approved the final } \\
\text { manuscript for } \\
\text { submission }\end{array}$ \\
\hline
\end{tabular}

\begin{tabular}{|c|c|c|c|}
\hline $\begin{array}{l}\text { Dawn C. } \\
\text { Buse, } \\
\text { PhD }\end{array}$ & $\begin{array}{l}\text { Albert Einstein College } \\
\text { of Medicine, Bronx, NY }\end{array}$ & Author & $\begin{array}{l}\text { Substantial } \\
\text { contributions to the } \\
\text { study conception and } \\
\text { design, analysis and } \\
\text { interpretation of the } \\
\text { data for the work, } \\
\text { revised the manuscript } \\
\text { for intellectual content, } \\
\text { and approved the final } \\
\text { manuscript for } \\
\text { submission }\end{array}$ \\
\hline
\end{tabular}

Appendix (continued)

\begin{tabular}{|c|c|c|c|}
\hline Name & Location & Role & Contribution \\
\hline $\begin{array}{l}\text { Vincent } \\
\text { T. Martin, } \\
\text { MD }\end{array}$ & $\begin{array}{l}\text { University of } \\
\text { Cincinnati Headache } \\
\text { and Facial Pain Center, } \\
\mathrm{OH}\end{array}$ & Author & $\begin{array}{l}\text { Substantial } \\
\text { contributions to the } \\
\text { analysis and } \\
\text { interpretation of the } \\
\text { data for the work, } \\
\text { revised the manuscript } \\
\text { for intellectual content, } \\
\text { and approved the final } \\
\text { manuscript for } \\
\text { submission }\end{array}$ \\
\hline
\end{tabular}

Lee B. CHC Group, LLC, an Author Drafted the manuscript

Hohaia, ICON plc company, and revised the

PharmD North Wales, PA manuscript under the guidance of the authors and approved the final manuscript for submission

\begin{tabular}{|c|c|c|c|}
\hline $\begin{array}{l}\text { Aubrey } \\
\text { Manack } \\
\text { Adams, } \\
\text { PhD }\end{array}$ & Allergan plc, Irvine, CA & Author & $\begin{array}{l}\text { Substantial } \\
\text { contributions to the } \\
\text { study conception and } \\
\text { design, analysis and } \\
\text { interpretation of the } \\
\text { data for the work, } \\
\text { revised the manuscript } \\
\text { for intellectual content, } \\
\text { and approved the final } \\
\text { manuscript for } \\
\text { submission }\end{array}$ \\
\hline $\begin{array}{l}\text { Michael } \\
\text { L. Reed, } \\
\text { PhD }\end{array}$ & $\begin{array}{l}\text { Vedanta Research, } \\
\text { Chapel Hill, NC }\end{array}$ & Author & $\begin{array}{l}\text { Substantial } \\
\text { contributions to the } \\
\text { study design, } \\
\text { acquisition, analysis, } \\
\text { and interpretation of } \\
\text { the data for the work, } \\
\text { revised the manuscript } \\
\text { for intellectual content, } \\
\text { and approved the final } \\
\text { manuscript for } \\
\text { submission }\end{array}$ \\
\hline
\end{tabular}

\begin{tabular}{|c|c|c|c|}
\hline $\begin{array}{l}\text { Peter J. } \\
\text { Goadsby, } \\
\text { MD, PhD }\end{array}$ & $\begin{array}{l}\text { UCSF Department of } \\
\text { Neurology, San } \\
\text { Francisco, CA; and } \\
\text { NIHR-Wellcome Trust } \\
\text { King's Clinical } \\
\text { Research Facility, } \\
\text { King's College, London, } \\
\text { UK }\end{array}$ & Author & $\begin{array}{l}\text { Substantial } \\
\text { contributions to the } \\
\text { analysis and } \\
\text { interpretation of the } \\
\text { data for the work, } \\
\text { revised the manuscript } \\
\text { for intellectual content, } \\
\text { and approved the final } \\
\text { manuscript for } \\
\text { submission }\end{array}$ \\
\hline
\end{tabular}

\section{References}

1. Louter MA, Fernandez-Morales J, de Vries B, et al. Candidate-gene association study searching for genetic factors involved in migraine chronification. Cephalalgia 2015;35:500-507.

2. Dahlof CG, Johansson M, Casserstedt S, Motallebzadeh T. The course of frequent episodic migraine in a large headache clinic population: a 12-year retrospective followup study. Headache 2009;49:1144-1152.

3. Bigal ME, Lipton RB. Migraine chronification. Curr Neurol Neurosci Rep 2011;11: 139-148.

4. Buse DC, Greisman JD, Baigi K, Lipton RB. Migraine progression: a systematic review. Headache 2019;59:306-338.

5. Chong CD, Gaw N, Fu Y, Li J, Wu T, Schwedt TJ. Migraine classification using magnetic resonance imaging resting-state functional connectivity data. Cephalalgia 2017;37:828-844.

6. Schwedt TJ, Si B, Li J, Wu T, Chong CD. Migraine subclassification via a data-driven automated approach using multimodality factor mixture modeling of brain structure measurements. Headache 2017;57:1051-1064.

7. Lipton RB, Fanning KM, Buse DC, et al. Identifying natural subgroups of migraine based on comorbidity and concomitant condition profiles: results of the Chronic Migraine Epidemiology and Outcomes (CaMEO) Study. Headache 2018;58:933-947. 
8. Peng $\mathrm{YH}$, Chen KF, Liao WC, et al. Association of migraine with asthma risk: a retrospective population-based cohort study. Clin Respir J 2018;12:1030-1037.

9. Martin VT, Fanning KM, Serrano D, et al. Chronic rhinitis and its association with headache frequency and disability in persons with migraine: results of the American Migraine Prevalence and Prevention (AMPP) Study. Cephalalgia 2014;34:336-348.

10. Chen YC, Tang CH, Ng K, Wang SJ. Comorbidity profiles of chronic migraine sufferers in a national database in Taiwan. J Headache Pain 2012;13:311-319.

11. Plesh O, Adams SH, Gansky SA. Self-reported comorbid pains in severe headaches or migraines in a US national sample. Headache 2012;52:946-956.

12. Martin VT, Fanning KM, Serrano D, Buse DC, Reed ML, Lipton RB. Asthma is a risk factor for new onset chronic migraine: results from the American Migraine Prevalence and Prevention Study. Headache 2016;56:118-131.

13. Ashina S, Serrano D, Lipton RB, et al. Depression and risk of transformation of episodic to chronic migraine. J Headache Pain 2012;13:615-624.

14. Scher AI, Buse DC, Fanning KM, et al. Comorbid pain and migraine chronicity: the Chronic Migraine Epidemiology and Outcomes Study. Neurology 2017;89:461-468.

15. Tietjen GE, Herial NA, Hardgrove J, Utley C, White L. Migraine comorbidity constellations. Headache 2007;47:857-865.

16. Manack Adams A, Serrano D, Buse DC, et al. The impact of chronic migraine: the Chronic Migraine Epidemiology and Outcomes (CaMEO) Study: methods and baseline results. Cephalalgia 2015;35:563-578.

17. Headache Classification Committee of the International Headache Society. The International Classification of Headache Disorders, 3rd edition. Cephalalgia 2018;38:1-211.

18. Lipton RB, Stewart WF, Diamond S, Diamond ML, Reed M. Prevalence and burden of migraine in the United States: data from the American Migraine Study II. Headache 2001;41:646-657.

19. Stewart WF, Lipton RB, Celentano DD, Reed ML. Prevalence of migraine headache in the United States: relation to age, income, race, and other sociodemographic factors. JAMA 1992;267:64-69.

20. Silberstein S, Loder E, Diamond S, Reed ML, Bigal ME, Lipton RB. Probable migraine in the United States: results of the American Migraine Prevalence and Prevention (AMPP) study. Cephalalgia 2007;27:220-229.

21. Silberstein SD, Lipton RB, Sliwinski M. Classification of daily and near-daily headaches: field trial of revised IHS criteria. Neurology 1996;47:871-875

22. Liebenstein M, Bigal M, Sheftell F, Tepper S, Rapoport A, Lipton R. Validation of the Chronic Daily Headache Questionnaire (CDH-Q), abstract F25. 49th Annual Scientific Meeting of the American Headache Society; 2007 June 7-11; Chicago, IL: 760-761.

23. Lipton RB, Manack Adams A, Buse DC, Fanning KM, Reed ML. A comparison of the Chronic Migraine Epidemiology and Outcomes (CaMEO) Study and American
Migraine Prevalence and Prevention (AMPP) study: demographics and headacherelated disability. Headache 2016;56:1280-1289.

24. Lipton RB, Bigal ME, Ashina S, et al. Cutaneous allodynia in the migraine population. Ann Neurol 2008;63:148-158.

25. Buse DC, Loder EW, Gorman JA, et al. Sex differences in the prevalence, symptoms, and associated features of migraine, probable migraine and other severe headache results of the American Migraine Prevalence and Prevention (AMPP) Study. Headache 2013;53:1278-1299.

26. Stewart WF, Lipton RB, Dowson AJ, Sawyer J. Development and testing of the Migraine Disability Assessment (MIDAS) Questionnaire to assess headache-related disability. Neurology 2001;56:S20-S28.

27. Tietjen GE, Brandes JL, Peterlin BL, et al. Allodynia in migraine: association with comorbid pain conditions. Headache 2009;49:1333-1344

28. Chen N, Zhang J, Wang P, Guo J, Zhou M, He L. Functional alterations of pain processing pathway in migraine patients with cutaneous allodynia. Pain Med 2015;16:1211-1220.

29. Katsarava Z, Schneeweiss S, Kurth T, et al. Incidence and predictors for chronicity of headache in patients with episodic migraine. Neurology 2004;62:788-790.

30. Bigal ME, Serrano D, Buse D, Scher A, Stewart WF, Lipton RB. Acute migraine medications and evolution from episodic to chronic migraine: a longitudinal population-based study. Headache 2008;48:1157-1168.

31. Zwart JA, Dyb G, Hagen K, Svebak S, Stovner LJ, Holmen J. Analgesic overuse among subjects with headache, neck, and low-back pain. Neurology 2004;62:1540-1544.

32. Bigal ME, Liberman JN, Lipton RB. Obesity and migraine: a population study. Neurology 2006;66:545-550.

33. Gelaye B, Sacco S, Brown WJ, Nitchie HL, Ornello R, Peterlin BL. Body composition status and the risk of migraine: a meta-analysis. Neurology 2017;88:1795-1804.

34. Lucke T, Herrera R, Wacker M, et al. Systematic analysis of self-reported comorbidities in large cohort studies: a novel stepwise approach by evaluation of medication. PLoS One 2016;11:e0163408.

35. Probyn K, Bowers H, Caldwell F, et al. Prognostic factors for chronic headache: a systematic review. Neurology 2017;89:291-301.

36. Lipton RB, Serrano D, Pavlovic JM, et al. Improving the classification of migrain subtypes: an empirical approach based on factor mixture models in the American Migraine Prevalence and Prevention (AMPP) Study. Headache 2014;54:830-849.

37. Serrano D, Lipton RB, Scher AI, et al. Fluctuations in episodic and chronic migraine status over the course of 1 year: implications for diagnosis, treatment and clinical trial design. J Headache Pain 2017;18:101. 


\section{Neurology}

Migraine progression in subgroups of migraine based on comorbidities: Results of the CaMEO Study

Richard B. Lipton, Kristina M. Fanning, Dawn C. Buse, et al.

Neurology 2019;93;e2224-e2236 Published Online before print November 5, 2019

DOI 10.1212/WNL.0000000000008589

This information is current as of November 5, 2019

\section{Updated Information \&} Services

References

Citations

Subspecialty Collections

Permissions \& Licensing

Reprints including high resolution figures, can be found at: http://n.neurology.org/content/93/24/e2224.full

This article cites 36 articles, 8 of which you can access for free at: http://n.neurology.org/content/93/24/e2224.full\#ref-list-1

This article has been cited by 2 HighWire-hosted articles: http://n.neurology.org/content/93/24/e2224.full\#\#otherarticles

This article, along with others on similar topics, appears in the following collection(s):

Migraine

http://n.neurology.org/cgi/collection/migraine

Risk factors in epidemiology

http://n.neurology.org/cgi/collection/risk_factors_in_epidemiology

Information about reproducing this article in parts (figures,tables) or in its entirety can be found online at:

http://www.neurology.org/about/about_the_journal\#permissions

Information about ordering reprints can be found online:

http://n.neurology.org/subscribers/advertise

Neurology ${ }^{\circledR}$ is the official journal of the American Academy of Neurology. Published continuously since 1951, it is now a weekly with 48 issues per year. Copyright Copyright (C) 2019 The Author(s). Published by Wolters Kluwer Health, Inc. on behalf of the American Academy of Neurology.. All rights reserved. Print ISSN: 0028-3878. Online ISSN: 1526-632X.

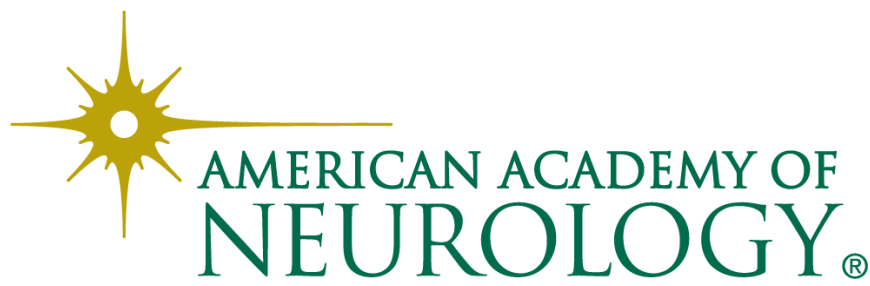

